\title{
QUANTIFICATION OF BILASTINE AND MONTELUKAST COMBINATION IN FORMULATIONS UTILIZING LIQUID CHROMATOGRAPHY: STABILITY STUDIES
}

\section{KANCHARLA VIJAYALAKSHMI ${ }^{*}$, BETHAPUDI SAMUEL ANAND ANDREWS ${ }^{2}$, BOLINENI NAGESWARA RAO ${ }^{3}$}

${ }^{1}$ Quality Control Department, Divis Laboratories Limited, Hyderabad, India 508252, ${ }^{2}$ Department of Chemistry, Gitam Institute of Technology, GITAM University, Visakhapatnam, India 530045, ${ }^{3}$ Research and Development, Divis Laboratories Limited, Hyderabad, India 500018

Email: vijayalakshmikancharla.msc@gmail.com

Received: 27 Apr 2021, Revised and Accepted: 30 Aug 2021

ABSTRACT

Objective: We have developed a "stability-indicating RP-HPLC" procedure for the Bilastine (BLS) and montelukast (MTL) analysis of tablets.

Methods: The quantification of BLS and MTL combination was implemented utilising a Waters column (C18, $5 \mu \mathrm{m}, 250 \mathrm{~mm}$ and $4.6 \mathrm{~mm}$ ). Isocratic mobile phase had $60 \%$ volume $\mathrm{KH}_{2} \mathrm{PO}_{4}$ of $0.1 \mathrm{M}$ strength with $\mathrm{pH} 4.2$ units and $40 \%$ volume methanol at a flow with $1.0 \mathrm{ml} / \mathrm{min}$ speed. UV detection at $232 \mathrm{~nm}$ was done to examine BLS and MTL. Stability experiments of BLS and MTL under distinctive environments of stress were also performed.

Results: The BLS and MTL were eluted at $1.810 \mathrm{~min}$ and $2.551 \mathrm{~min}$, respectively. The responses were found to be linear for the concentration ranges of $10-30 \mu \mathrm{g} / \mathrm{ml}$ (BLS) and $5-15 \mu \mathrm{g} / \mathrm{ml}$ (MTL). Percent comparative standard deviance for precision was $0.331 \%$ (BLS) and $0.486 \%$ (MTL). Percent assay for accuracy was $98.96 \%$ (BLS) and 99.00\% (MTL). The detection limit and quantitation limit measures for BLS were $0.018 \mu \mathrm{g} / \mathrm{ml}$ and $0.059 \mu \mathrm{g} / \mathrm{ml}$, respectively, while for MTL it was $0.024 \mu \mathrm{g} / \mathrm{ml}$ and $0.081 \mu \mathrm{g} / \mathrm{ml}$, respectively. Robustness studies authorized that the method is robust with percent comparative standard deviance of a highest $1.950 \%$.

Conclusion: The developed "stability-indicating RP-HPLC" procedure for the BLS and MTL analysis is simple, sensitive, precise, specific and robust, making it appropriate to the assessment of BLS and MTL in a tablet formulation.

Keywords: Bilastine, Montelukast, Tablet formulation, Stability indicating, Analysis

(C) 2021 The Authors. Published by Innovare Academic Sciences Pvt Ltd. This is an open access article under the CC BY license (https://creativecommons.org/licenses/by/4.0/) DOI: https://dx.doi.org/10.22159/ijap.2021v13i6.41915. Journal homepage: https://innovareacademics.in/journals/index.php/ijap

\section{INTRODUCTION}

Nonsedating antihistamines are the first treatment option for the allergic rhinoconjunctivitis including urticaria, according to the existing recommendations $[1,2]$. Bilastine (BLS) is not structurally relevant to many other antihistamines. BLS, like loratadine, desloratadine, even fexofenadine, falls in the piperidine grouping of antihistamines. BLS, as many other antihistamines, is also an inverse agonist for the $\mathrm{H} 1$ receptor. The in vitro tests have revealed that the BLS affinity with the $\mathrm{H} 1$ receptor is significant, but the affinity with 30 other checked receptors is very weak, or very little [3]. The in vivo tests have revealed histamine excited smooth muscle relaxation, endothelial permeability, bronchospasms, and microvascular extravasation were all decreased in the rats [4]. The suppression of histamine excited wheal and flare reaction behaviour in the skin, which was marked with BLS, was reported in vivo tests in the human populace.

From the findings of both comparative observations of montelukast (MLT) versus placebo and findings of MLT's preventive role on the bronchoconstriction occasioned by exercise or any other nonspecific triggers were reported, the first indications of MLT's efficacy in asthma were recorded [5]. MLT is a cysteinyl leukotriene receptor blocker that is intended to manage asthma as well as alleviate seasonal allergies signs. MLT works via attaching to a cysteinyl leukotriene receptor in the bronchial tubes and lungs and suppressing the operation of leukotriene D4 on it [6]. In mild-tomoderate asthmatics that are not taking inhaled corticosteroids, MLT improves symptoms, relief drug use, and pulmonary functioning as well as lowering the frequency of exacerbation and blood eosinophil quantities. Montelukast also outperformed longacting beta2-agonists in preventing bronchoconstriction exacerbated by exercise [7].

The BLS and MTL structures were displayed in fig. 1. One publication resulted from a study of BLS and MTL absorbance grounded assays, suggesting BLS and MTL direct quantitative evaluation in the pharmaceutical dosage types [8]. BLS and MTL absorption at $214 \mathrm{~nm}$ and $281 \mathrm{~nm}$, respectively, are used in their quantitation. For BLS and
MTL analysis of tablets, no liquid chromatography-based approach has been put forward yet. In this investigation project, we developed a "stability-indicating RP-HPLC" method for the BLS and MTL analysis of tablets. We also studied the validated factors of "stabilityindicating RP-HPLC" method proposed for the BLS and MTL analysis.
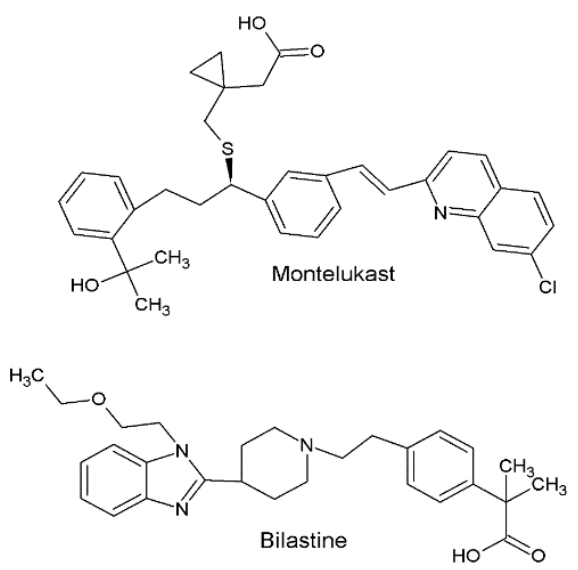

Fig. 1: BLS (bilastine) and MTL (montelukast) structures

\section{MATERIALS AND METHODS}

\section{Chemicals}

The BLS and MTL combination tablet kind used was Bilagio M (BLS $20 \mathrm{mg}$ and MTL $10 \mathrm{mg}$, "Synokem Pharmaceuticals LTD, India"). "Rainbow Pharma Training Labs, India" provided the BLS and MTL reference samples. Methanol (Merck, India) and water (Milli Q water) utilized in "stability-indicating RP-HPLC" experiments were HPLC rating. $\mathrm{NaOH}, \mathrm{H}_{2} \mathrm{PO}_{4}, \mathrm{H}_{2} \mathrm{O}_{2}, \mathrm{KH}_{2} \mathrm{PO}_{4}$ and $\mathrm{HCl}$ were all reagent rating from "Sd Fine Chemicals Ltd, India". 


\section{Apparatus}

The "stability-indicating RP-HPLC" studies were carried out on a Waters Corporation 2965 model high-performance liquid chromatography machine, which again was fitted with a PDA 2998 detector. The "stability-indicating RP-HPLC" quantification of the BLS and MTL combination was implemented, consuming a Waters column (C18, $5 \mu \mathrm{m}, 250 \mathrm{~mm}$ and $4.6 \mathrm{~mm}$ ).

\section{BLS and MTL solutions}

Stock BLS and MTL solution was freshly formulated in the diluent at quantities of $200 \mu \mathrm{g} / \mathrm{ml}$ (BLS) and $100 \mu \mathrm{g} / \mathrm{ml}$ (MTL). Stock BLS (200 $\mu \mathrm{g} / \mathrm{ml})$ and MTL $(100 \mu \mathrm{g} / \mathrm{ml})$ solution was next used to make fresh working BLS $(20 \mu \mathrm{g} / \mathrm{ml})$ and MTL $(10 \mu \mathrm{g} / \mathrm{ml})$ solution and calibration BLS (range: $10-30 \mu \mathrm{g} / \mathrm{ml}$ ) and MTL (range: $5-15 \mu \mathrm{g} / \mathrm{ml}$ ) solutions by diluting a proper volumes of stock BLS $(200 \mu \mathrm{g} / \mathrm{ml})$ and MTL $(100 \mu \mathrm{g} / \mathrm{ml})$ solution with diluent.

\section{BLS and MTL analysing conditions}

Mobile phase had $60 \%$ volume $\mathrm{KH}_{2} \mathrm{PO}_{4}$ of $0.1 \mathrm{M}$ strength with $\mathrm{pH} 4.2$ units and $40 \%$ volume methanol at a flow with $1.0 \mathrm{ml} / \mathrm{min}$ speed. Temperature inside column, injector sample size and wavelength for the BLS and MTL enumeration was tuned at $25^{\circ} \mathrm{C}, 10 \mu \mathrm{l}$ and $232 \mathrm{~nm}$, respectively. For the processing of BLS and MTL solutions, the mobile phase solvents blend was considered as a diluent.

\section{BLS and MTL linearity curves}

Prepared calibration BLS (range: 10-30 $\mu \mathrm{g} / \mathrm{ml}$ ) and MTL (range: 5$15 \mu \mathrm{g} / \mathrm{ml}$ ) solutions by diluting proper volumes of stock BLS (200 $\mu \mathrm{g} / \mathrm{ml})$ and MTL $(100 \mu \mathrm{g} / \mathrm{ml})$ solution with the diluent. The BLS and MTL peak areas of the formulated solutions were reported at 232 $\mathrm{nm}$ under the proposed "stability-indicating RP-HPLC" method's conditions. The BLS and MTL peak areas recorded were next plotted against the related BLS and MTL concentrations. Thus, linearity curves for BLS and MTL were constructed which is followed by computation of regression equation.

\section{Tablet analysis}

Ten tablets of BLS and MTL commercial formulation, Bilagio M, was balanced and pounded. A portion of Bilagio M powder corresponding to BLS $20 \mathrm{mg}$ and MTL $10 \mathrm{mg}$ was correctly placed in a $100 \mathrm{ml}$ flask and sonicated about $30 \mathrm{~min}$ with $50 \mathrm{ml}$ diluent. Filtered this solution via membrane paper filter into a $100 \mathrm{ml}$ another flask and finalized to $100 \mathrm{ml}$ indication with the diluent. This is stock Bilagio M solution $(200 \mu \mathrm{g} / \mathrm{ml}-\mathrm{BLS}$ and $100 \mu \mathrm{g} / \mathrm{ml}-\mathrm{MTL})$. Stock Bilagio M solution was next used to make fresh working Bilagio M solution $(20 \mu \mathrm{g} / \mathrm{ml}-\mathrm{BLS}$ and $10 \mu \mathrm{g} / \mathrm{ml}-\mathrm{MTL}$ ). The BLS and MTL peak areas of the formulated solutions were reported at $232 \mathrm{~nm}$ under the proposed "stability indicating RP-HPLC" method's conditions. Using peak areas of BLS and MTL, their content in Bilagio M tablets were assessed using corresponding linearity curves or regression formulas.

\section{BLS and MTL degradation investigation}

Using Bilagio M solution, stress degradation of BLS and MTL under alkaline, acidic, photolytic, oxidative, and thermal environments were conducted [9].

\section{Acidic condition}

The stock Bilagio M solution (200 $\mu \mathrm{g} / \mathrm{ml}-\mathrm{BLS}$ and $100 \mu \mathrm{g} / \mathrm{ml}-\mathrm{MTL})$ was prepared. Ten millilitres each of stock Bilagio $M$ solution and $0.1 \mathrm{~N} \mathrm{HCl}$ were correctly placed in a $100 \mathrm{ml}$ flask and sonicated at ambient temperature for about $30 \mathrm{~min}$. Filtered this solution via membrane paper filter into $100 \mathrm{ml}$ another flask and finalized to 100 $\mathrm{ml}$ indication with diluent. The BLS and MTL peak areas of degraded specimen solution were reported at $232 \mathrm{~nm}$ under the proposed "stability-indicating RP-HPLC" method's conditions.

\section{Alkaline condition}

Prepared stock Bilagio M solution $(200 \mu \mathrm{g} / \mathrm{ml}-\mathrm{BLS}$ and $100 \mu \mathrm{g} / \mathrm{ml}-$ MTL). Sonicated ten millilitres each of stock Bilagio $M$ solution and $0.1 \mathrm{~N} \mathrm{NaOH}$ that were correctly placed in a $100 \mathrm{ml}$ flask at ambient temperature for around $30 \mathrm{~min}$. Filtered this solution via membrane paper filter into $1000 \mathrm{l}$ another flask and finalized to $100 \mathrm{ml}$ indication with the diluent. Under the proposed "stability-indicating RP-HPLC" method's conditions, the BLS and MTL peak areas of degraded specimen solution were recorded at $232 \mathrm{~nm}$.

\section{Oxidative condition}

The stock Bilagio M solution (200 $\mu \mathrm{g} / \mathrm{ml}-\mathrm{BLS}$ and $100 \mu \mathrm{g} / \mathrm{ml}-\mathrm{MTL})$ was prepared. Ten milliliters each of stock Bilagio $M$ solution and $30 \%$ peroxide were correctly placed in a $100 \mathrm{ml}$ flask and sonicated at ambient temperature for around 30 min. Filtered this solution via membrane paper filter into $100 \mathrm{ml}$ another flask and finalized to 100 $\mathrm{ml}$ indication with the diluent. Under the proposed "stabilityindicating RP-HPLC" method's conditions, the BLS and MTL peak areas of degraded specimen solution were recorded at $232 \mathrm{~nm}$.

\section{Thermal condition}

Ten millilitres of stock Bilagio M solution $(200 \mu \mathrm{g} / \mathrm{ml}-\mathrm{BLS}$ and 100 $\mu \mathrm{g} / \mathrm{ml}-\mathrm{MTL}$ ) was correctly placed in a $100 \mathrm{ml}$ flask and exposed at $60{ }^{\circ} \mathrm{C}$ temperature for around $30 \mathrm{~min}$. Filtered this solution via membrane paper filter into $100 \mathrm{ml}$ another flask and finalized to 100 $\mathrm{ml}$ indication with the diluent. Under the proposed "stabilityindicating RP-HPLC" method's conditions, the BLS and MTL peak areas of degraded specimen solution were recorded at $232 \mathrm{~nm}$.

\section{Photo condition}

Exposed ten millilitres of stock Bilagio M solution $(200 \mu \mathrm{g} / \mathrm{ml}-\mathrm{BLS}$ and $100 \mu \mathrm{g} / \mathrm{ml}-\mathrm{MTL}$ ) that was correctly placed in a $100 \mathrm{ml}$ flask to sunlight for nearby $24 \mathrm{hr}$. Filtered this solution via membrane paper filter into $100 \mathrm{ml}$ another flask and finalized to $100 \mathrm{ml}$ indication with the diluent. Under the proposed "stability-indicating RP-HPLC" method's conditions, the BLS and MTL peak areas of degraded specimen solution were recorded at $232 \mathrm{~nm}$.

\section{Validation}

The validation factors, including selectivity, linearity, repeatability, accuracy, robustness and specificity, were checked that are agreed in ICH recommendation [10-12].

\section{RESULTS}

The major emphasis of this report is to establish a "stability implying RP-HPLC" system for determining BLS and MTL in tablets. Following multiple tentative trails, the following chromatographic settings were deemed to be desirable for determining BLS and MTL in tablets: Mobile phase- $60 \%$ volume $\mathrm{KH}_{2} \mathrm{PO}_{4}$ of $0.1 \mathrm{M}$ strength with $\mathrm{pH}$ 4.2 units and $40 \%$ volume methanol at a flow with $1.0 \mathrm{ml} / \mathrm{min}$ speed, $25{ }^{\circ} \mathrm{C}$ of temperature inside column, $10 \mu \mathrm{l}$ size of injection sample and $232 \mathrm{~nm}$ of wavelength for BLS and MTL enumeration. Chromatogram of BLS and MTL is made known in fig. 2.

\section{Linearity}

The calibration curves were obtained for BLS and MTL by injection $(10 \mu \mathrm{l}$ volume) of calibration BLS (range: $10-30 \mu \mathrm{g} / \mathrm{ml}$ ) and MTL (range: $5-15 \mu \mathrm{g} / \mathrm{ml}$ ) solutions. BLS and MTL area below their peaks were marked set against the corresponding BLS and MTL concentrations (fig. 3). The regression coefficient scores for the BLS and MTL and regression line formulas for BLS and MTL were:

$$
\begin{aligned}
& \text { For BLS-y = } 123080 x-18048 ; \mathrm{R}^{2} \text { score- } 0.9999 \\
& \text { For MTL-y = } 112576 x+8657.6 ; \mathrm{R}^{2} \text { score- } 0.9997
\end{aligned}
$$

\section{Sensitivity}

The "detection limit" (D-L) and "quantitation limit" (Q-L) are sensitivity parameters. These are computed utilising the ICH indorsed criteria [10]. The D-L and Q-L measures for BLS are 0.018 $\mu \mathrm{g} / \mathrm{ml}$ and $0.059 \mu \mathrm{g} / \mathrm{ml}$, respectively, while for MTL it was 0.024 $\mu \mathrm{g} / \mathrm{ml}$ and $0.081 \mu \mathrm{g} / \mathrm{ml}$, respectively.

\section{Precision}

Repeatability was evaluated with the working BLS $(20 \mu \mathrm{g} / \mathrm{ml})$ and MTL $(10 \mu \mathrm{g} / \mathrm{ml})$ solution injected (10 $\mu \mathrm{l}$ volume) six number of times. Mean, SD and \% RSD for BLS and MTL peak areas acquired was evaluated (table 1).

\section{Accuracy}

Accuracy was evaluated with the working BLS $(20 \mu \mathrm{g} / \mathrm{ml})$ and MTL $(10 \mu \mathrm{g} / \mathrm{ml})$ solution injected (10 $\mu \mathrm{l}$ volume) six number of times. Mean, SD and \% RSD for BLS and MTL content assay acquired was evaluated (table 1). 


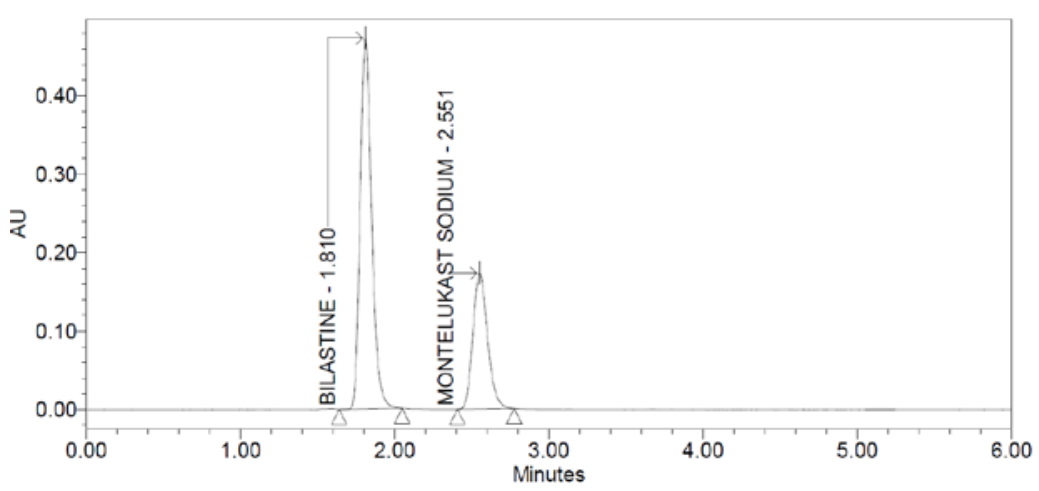

Fig. 2: Chromatogram of BLS (bilastine) and MTL (montelukast)
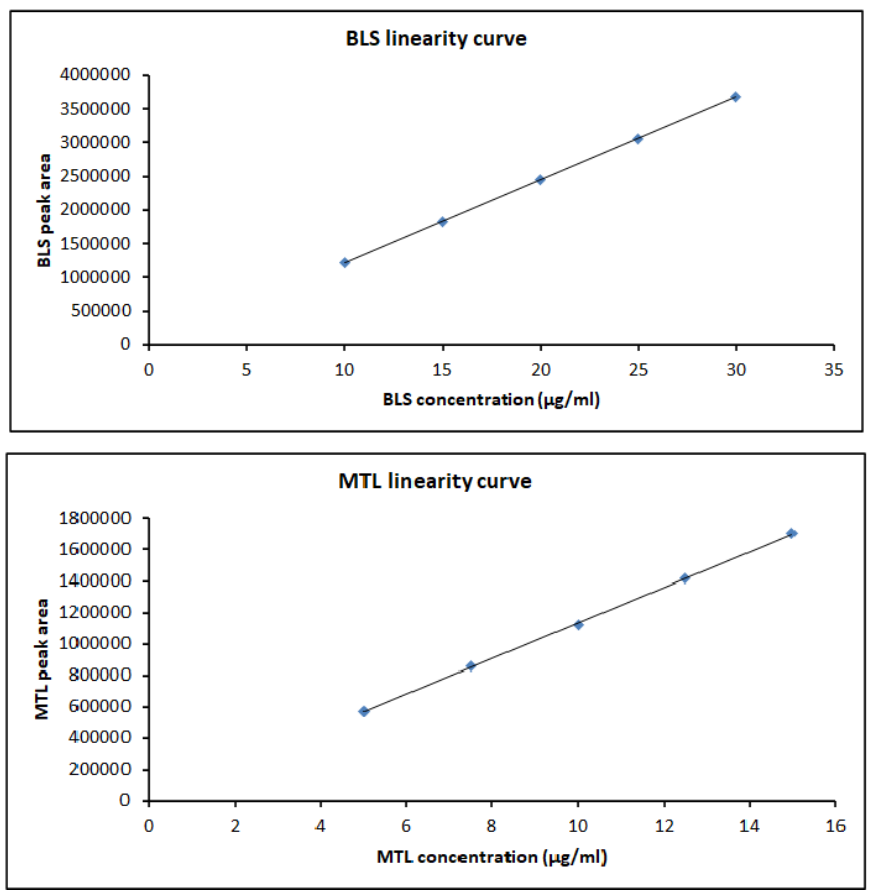

Fig. 3: BLS (bilastine) and MTL (montelukast) linearity curves

Table 1: BLS and MTL analysis precision and accuracy measures

\begin{tabular}{|c|c|c|c|c|}
\hline Injection & BLS Area & MTL Area & BLS \% Assay & MTL \% Assay \\
\hline $\mathrm{I}$ & 2446909 & 1140264 & 99.16 & 99.05 \\
\hline II & 2448991 & 1139441 & 99.24 & 98.98 \\
\hline III & 2434640 & 1130618 & 98.66 & 98.21 \\
\hline IV & 2436827 & 1147820 & 98.75 & 99.71 \\
\hline V & 2451658 & 1138647 & 99.35 & 98.91 \\
\hline VI & 2433083 & 1141501 & 98.60 & 99.16 \\
\hline Mean value (n) & 2442018 & 1139715 & 98.96 & 99.00 \\
\hline SD value & 8083.19 & 5534.498 & 0.328 & 0.481 \\
\hline RSD value & 0.331 & 0.486 & 0.331 & 0.486 \\
\hline
\end{tabular}

SD-standard deviation; R. SD-Relative standard deviation; $\mathrm{n}=6$ number of experiments

\section{BLS and MTL degradation}

BLS and MTL degradation under alkaline, acidic, photolytic, oxidative, and thermal environments revealed the results as follows: In an acidic environment, BLS and MTL were degraded by $10.08 \%$ and 9.54\%, respectively. Alkaline environment degraded BLS and MTL at $7.59 \%$ and $6.36 \%$, respectively. $4.73 \%$ of BLS and $8.26 \%$ of MTL were degraded in oxidative environments. When subjected to
$60{ }^{\circ} \mathrm{C}$ temperature, $10.55 \%$ of BLS and $10.26 \%$ of MTL were degraded. In sunlight, BLS and MTL were degraded by $8.51 \%$ and $5.73 \%$, respectively. The corresponding BLS and MTL degraded chromatograms are shown off in fig. 4. In acidic, photolytic, and thermal environments, four new peaks were detected in addition to the BLS and MTL peaks. While in alkaline and oxidative environments, three new peaks were detected in addition to the BLS and MTL peaks. 

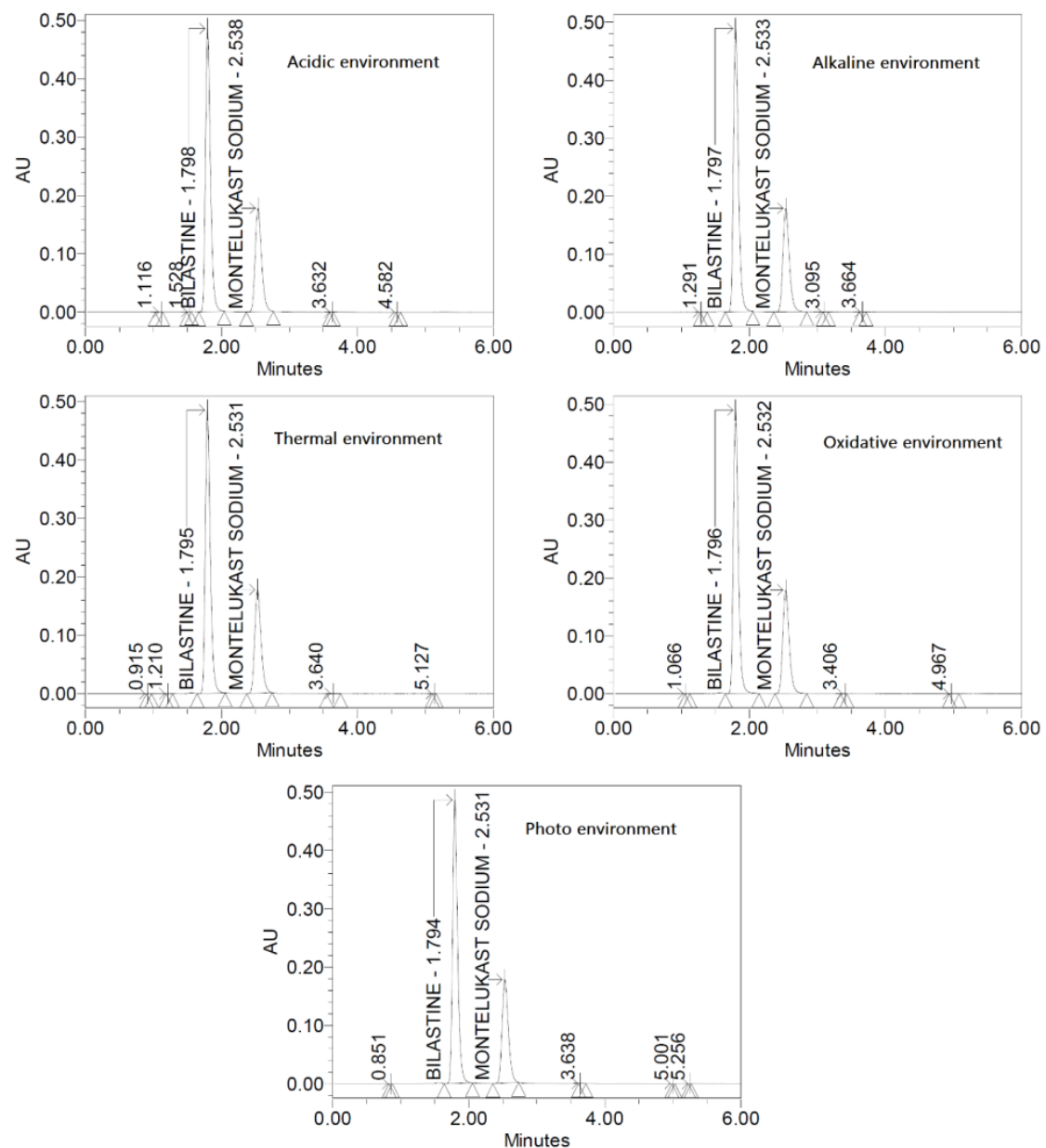

Fig. 4: BLS (bilastine) and MTL (montelukast) degradation investigation chromatograms

Table 2: BLS and MTL recovery measures

\begin{tabular}{|c|c|c|c|c|c|c|}
\hline Added level & $\mu \mathrm{g} / \mathrm{ml} \mathrm{BLS}$ added & $\mu \mathrm{g} / \mathrm{ml}$ BLS found & \% BLS Recovery & Mean value (n) & SD value & RSD value \\
\hline \multirow[t]{3}{*}{$50 \%$} & 9.900 & 9.88 & 99.81 & 99.36 & 0.408 & 0.411 \\
\hline & 9.900 & 9.83 & 99.27 & & & \\
\hline & 9.900 & 9.80 & 99.01 & & & \\
\hline \multirow[t]{3}{*}{$100 \%$} & 19.800 & 19.71 & 99.54 & 99.77 & 0.308 & 0.309 \\
\hline & 19.800 & 19.82 & 100.12 & & & \\
\hline & 19.800 & 19.73 & 99.65 & & & \\
\hline \multirow[t]{3}{*}{$150 \%$} & 29.700 & 29.66 & 99.88 & 100.00 & 0.161 & 0.161 \\
\hline & 29.700 & 29.75 & 100.18 & & & \\
\hline & 29.700 & 29.68 & 99.93 & & & \\
\hline Added level & $\mu \mathrm{g} / \mathrm{ml}$ MTL added & $\mu \mathrm{g} / \mathrm{ml}$ MTL found & \% MTL recovery & Mean value (n) & SD value & RSD value \\
\hline \multirow[t]{3}{*}{$50 \%$} & 4.950 & 4.96 & 100.23 & 100.32 & 0.145 & 0.144 \\
\hline & 4.950 & 4.97 & 100.49 & & & \\
\hline & 4.950 & 4.96 & 100.25 & & & \\
\hline \multirow{3}{*}{$100 \%$} & 9.900 & 9.69 & 97.89 & 98.17 & 0.869 & 0.885 \\
\hline & 9.900 & 9.81 & 99.14 & & & \\
\hline & 9.900 & 9.65 & 97.47 & & & \\
\hline \multirow[t]{3}{*}{$150 \%$} & 14.850 & 14.84 & 99.95 & 99.70 & 0.255 & 0.256 \\
\hline & 14.850 & 14.81 & 99.70 & & & \\
\hline & 14.850 & 14.77 & 99.44 & & & \\
\hline
\end{tabular}

SD-standard deviation; RSD-Relative standard deviation; $\mathrm{n}=3$ number of experiments

\section{Recovery}

A recognised amount of BLS $(9.90,19.80$ and $29.70 \mu \mathrm{g} / \mathrm{ml})$ and MTL (4.95, 9.90 and $14.85 \mu \mathrm{g} / \mathrm{ml}$ ) comparable to make claims of $50 \%$, $100 \%$ and $150 \%$ were included to the working Bilagio M solution $(20 \mu \mathrm{g} / \mathrm{ml}-\mathrm{BLS}$ and $10 \mu \mathrm{g} / \mathrm{ml}-\mathrm{MTL})$. The prepared specimen analysis was conceded three times under the proposed HPLC method's conditions. At every BLS and MTL concentration level, recoveries of BLS and MTL were gauged (table 2).

\section{Robustness}

The factors preferred for evaluating the robustness were: variation in wavelength $(+2 \mathrm{~nm},-2 \mathrm{~nm})$, flow rate $(+0.1 \mathrm{ml} / \mathrm{min}--0.1$ 
$\mathrm{ml} / \mathrm{min}$ ), methanol proportion ( $+5 \%$ volume, $-5 \%$ volume), $\mathrm{pH}(+0.1$ unit, -0.1 unit) and column's temperature $\left(+, 2{ }^{\circ} \mathrm{C},-2{ }^{\circ} \mathrm{C}\right)$. Robustness was inspected with the working BLS $(20 \mu \mathrm{g} / \mathrm{ml})$ and MTL $(10 \mu \mathrm{g} / \mathrm{ml})$ solution. The outcome of altered factors on the analysis of BLS and MTL was assessed in relations of Mean, SD and \%RSD for BLS and MTL peak areas acquired (table 3).

\section{System suitability}

System suitability was inspected with the working BLS $(20 \mu \mathrm{g} / \mathrm{ml})$ and MTL $(10 \mu \mathrm{g} / \mathrm{ml})$ solution. The Mean, SD and \%RSD for resolution, peak area, retention period, peak symmetry and theoretical plate number were determined (table 4) for BLS and MTL peaks conferring to ICH indorsed criteria [10].

Table 3: BLS and MTL robustness measures

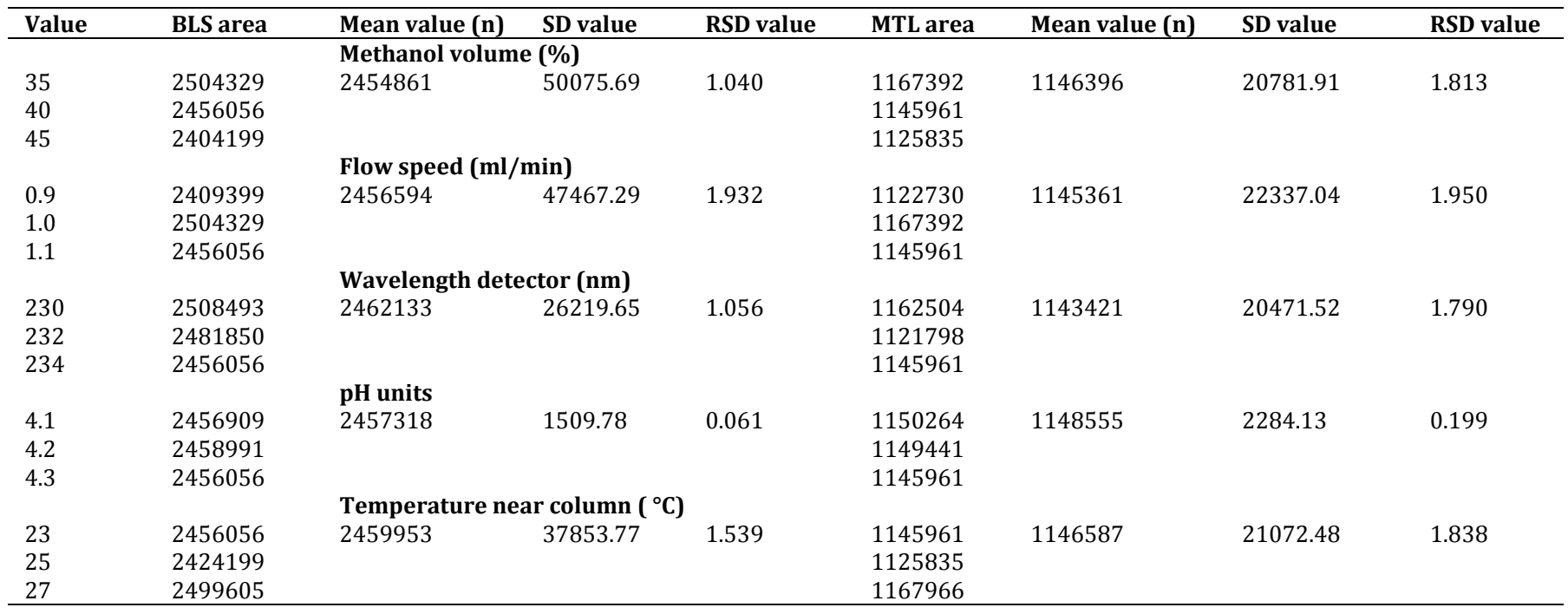

SD-standard deviation; R. SD-Relative standard deviation; $\mathrm{n}=3$ number of experiments

Table 4: BLS and MTL system suitability measures

\begin{tabular}{|c|c|c|c|c|c|}
\hline Injection & BLS Retention time & BLS Area & BLS peak plate count & BLS peak tailing & Resolution \\
\hline I & 1.808 & 2459329 & 7871 & 1.25 & - \\
\hline II & 1.810 & 2458037 & 7980 & 1.24 & - \\
\hline III & 1.809 & 2459859 & 7926 & 1.24 & - \\
\hline IV & 1.810 & 2467652 & 7984 & 1.24 & - \\
\hline $\mathrm{V}$ & 1.807 & 2456779 & 7921 & 1.23 & - \\
\hline Mean value (n) & 1.809 & 2460331 & 7936.400 & 1.240 & - \\
\hline SD value & 0.0013 & 4263.3018 & 46.8754 & 0.0071 & - \\
\hline RSD value & 0.072 & 0.173 & 0.591 & 0.570 & \\
\hline Injection & MTL Retention time & MTL Area & MTL peak plate count & MTL peak tailing & Resolution \\
\hline I & 2.548 & 1144916 & 8500 & 1.20 & 4.71 \\
\hline II & 2.550 & 1156005 & 8527 & 1.20 & 4.75 \\
\hline III & 2.548 & 1145056 & 8530 & 1.20 & 4.73 \\
\hline IV & 2.550 & 1146465 & 8596 & 1.19 & 4.78 \\
\hline $\mathrm{V}$ & 2.548 & 1151907 & 8570 & 1.19 & 4.8 \\
\hline Mean value (n) & 2.549 & 1148870 & 8544.600 & 1.196 & 4.754 \\
\hline S. D value & 0.0011 & 4901.4368 & 38.0762 & 0.0055 & 0.0365 \\
\hline R. S. D value & 0.043 & 0.427 & 0.446 & 0.458 & 0.767 \\
\hline
\end{tabular}

SD-standard deviation; R. SD-Relative standard deviation; $\mathrm{n}=6$ number of experiments

\section{DISCUSSION}

High values of coefficient regression scores for the BLS and MTL determined indicated the worthy linearity of "stability implying RPHPLC" system proposed for the BLS and MTL analysis [10, 13]. The very low measures of "detection limit" (D-L) and "quantitation limit" (Q-L) for the BLS and MTL determined indicated the desirable sensitivity of "stability implying RP-HPLC" system proposed for the BLS and MTL analysis [10, 14]. The enumerated recovery (table 2) achieves of BLS and MTL endorsing the selectivity besides noninterruption of the excipients in Bilagio $M$ formulation $[10,14]$.

The $0.331 \%$ and $0.486 \%$ RSD measures for BLS and MTL, respectively proved the preciseness of the "stability implying RPHPLC" system proposed. The $98.96 \%$ assay value measure for BLS and $99.00 \%$ assay value measures for the MTL proved accurateness of "stability implying RP-HPLC" system proposed $[10,15]$.
The method's stability suggesting the versatility has been evidenced by the sufficient segregation of all possible BLS and MTL degradation products (fig. 4) that were caused using alkaline, acidic, photolytic, oxidative, and thermal environments that are agreed in ICH recommendation [9,16-19]. BLS stability was in order of: Oxidative environment $>$ Alkaline environment $>$ Photo environment $>$ Acidic environment $>$ Thermal environment. MTL stability was in order of: Photo environment $>$ Alkaline environment $>$ Oxidative environment $>$ Acidic environment $>$ Thermal environment

Change in wavelength $(+2 \mathrm{~nm},-2 \mathrm{~nm})$, flow rate $(+0.1 \mathrm{ml} / \mathrm{min},-0.1$ $\mathrm{ml} / \mathrm{min})$, methanol proportion $(+5 \%$ volume, $-5 \%$ volume $), \mathrm{pH}(+0.1$ unit,-0.1 unit) and column's temperature $\left(+, 2{ }^{\circ} \mathrm{C},-2{ }^{\circ} \mathrm{C}\right)$ caused not beyond than $2 \%$ variance in the peak areas of BLS and MTL (table 3). This endorses robustness $[10,20]$. The measures of the resolution, peak area, retention period, peak symmetry and theoretical plate 
number determined (table 4) for BLS and MTL proved the suitableness of the device for analysing the BLS and MTL combination $[10,21]$.

\section{CONCLUSION}

A "Stability implying RP-HPLC" method was suggested for the BLS and MTL determination in the Bilagio $\mathrm{M}$ formulation lacking excipients interference. The suggested approach has a faster run time. The method projected herein signifies the first effort for BLS and MTL determination in the dosage varieties. The system would also be applied to conduct standard quality management assessment of both BLS and MTL in the authorized pharmaceutical preparations that comprise both BLS and MTL.

\section{ACKNOWLEDGEMENT}

Authors wish to acknowledge GITAM Deemed to be University (Visakhapatnam, India), Rainbow Pharma Training Lab (Hyderabad, India), Dr. B. Nageswara rao, General Manager, Divis laboratories limited (Hyderabad, India) and Kolasani Srikanth, Assistant General Manager, Divis laboratories limited (Hyderabad, India) to carry out this work.

\section{FUNDING}

Nil

\section{AUTHORS CONTRIBUTIONS}

All authors have contributed equally.

\section{CONFLICTS OF INTERESTS}

Declared none

\section{REFERENCES}

1. Bousquet J, Khaltaev N, Cruz AA, Denburg J, Fokkens WJ, Togias A. Allergic Rhinitis and its Impact on Asthma (ARIA) 2008 update (in collaboration with the World Health Organization, GA(2)LEN and AllerGen). Allergy. 2008;63;Suppl 86:8-160. doi: 10.1111/j.1398-9995.2007.01620.x, PMID 18331513.

2. Bousquet J, Van Cauwenberge PV, Khaltaev N, Aria Workshop Group, World Health Organization. Allergic rhinitis and its impact on asthma. J Allergy Clin Immunol. 2001; 108(5);Suppl:S147-334. doi: 10.1067/mai.2001.118891, PMID 11707753.

3. Corcóstegui R, Labeaga L, Innerarity A, Berisa A, Orjales A. Preclinical pharmacology of bilastine, a new selective histamine $\mathrm{H} 1$ receptor antagonist: receptor selectivity and in vitro antihistaminic activity. Drugs R D. 2005;6(6):371-84. doi: 10.2165/00126839-200506060-00005, PMID 16274260.

4. Corcóstegui R, Labeaga L, Innerárity A, Berisa A, Orjales A. In vivo pharmacological characterisation of bilastine, a potent and selective histamine $\mathrm{H} 1$ receptor antagonist. Drugs R D. 2006;7(4):219-31. doi: 10.2165/00126839-200607040-00002, PMID 16784247.

5. Paggiaro P, Bacci E. Montelukast in asthma: a review of its efficacy and place in therapy. Ther Adv Chronic Dis. 2011;2(1):47-58. doi: 10.1177/2040622310383343, PMID 23251741.

6. Baig S, Khan RA, Khan K, Rizvi N. Effectiveness and quality of life with montelukast in asthma- A double-blind, randomized control trial.Pak J Med Sci. 2019;35(3):731-36. doi: 10.12669/pjms.35.3.42, PMID 31258585.

7. Hon KL, Leung TF, Leung AK. Clinical effectiveness and safety of montelukast in asthma. What are the conclusions from clinical trials and meta-analyses? Drug Des Dev Ther. 2014;8:839-50. doi: 10.2147/DDDT.S39100, PMID 25061277.

8. Raj RM, Sankar ASK, Vetrichelvan T. Analytical method development and validation for simultaneous estimation of bilastine and montelukast sodium by UV spectrophotometry. World J Pharm Pharm Sci. 2020;10:680-7.

9. International Conference on Harmonization (ICH). Stability testing of new drug substances and products Q1A. Vol. R2. Geneva, Switzerland; 2003.

10. International Conference on Harmonization (ICH). Harmonized tripartite guideline validation of analytical procedures: text and methodology Q2. Vol. R1. Switzerland; 2005.

11. Ravichandran V, Shalini S, Sundaram KM, Rajak H. Validation of analytical methods-strategies and importance. Int J Pharm Pharm Sci. 2010;2:18-22.

12. Sharma S, Goyal S, Chauhan K. A review on analytical method development and validation. Int J App Pharm. 2018;10(6):8-15. doi: 10.22159/ijap.2018v10i6.28279.

13. Panchumarthy R, Navya ChN, Pravallika D, Sri DN. A review on step-by-step analytical method validation. IOSR J Pharm. 2015;5:7-19.

14. Locatelli M, Melucci D, Carlucci G, Locatelli C. Recent HPLC strategies to improve sensitivity and selectivity for the analysis of complex matrices. Instrum Sci Technol. 2012;40(2-3):11237. doi: $10.1080 / 10739149.2011 .651668$.

15. Betz JM, Brown PN, Roman MC. Accuracy, precision, and reliability of chemical measurements in natural products research. Fitoterapia. 2011;82(1):44-52. doi: 10.1016/j.fitote.2010.09.011, PMID 20884340.

16. Soumia B, Fatima H, Saïd B, Bouchaib B, Souad T, Souad H, Ahmed B, Abdelmjid A. Statistical tools and approaches to validate analytical methods: methodology and practical examples. Int J Metrol Qual Eng. 2017;8:1-10.

17. Rode DM, Rao NN. A review on development and validation of stability-indicating HPLC methods for the analysis of acidic drugs. Int J Curr Pharm Sci. 2019;11:22-33. doi: 10.22159/ijcpr.2019v11i4.34939.

18. Rajasingam R, Sagineedu SR, Tan YH, Nalaiya J, Pichika MR. stress degradation studies and development of a validated RPHPLC method for determination of tiagabine in the presence of its degradation products. Int J Pharm Pharm Sci. 2016;8:230-6.

19. Rao PV, Rao AL, Svum P. Development and validation of new stability-indicating reversed-phase high-performance liquid chromatography method for simultaneous determination of metformin hydrochloride and ertugliflozin in the bulk and pharmaceutical dosage form. Asian J Pharm Clin Res. 2019;12(1):235-40. doi: 10.22159/ajpcr.2019.v12i1.28938.

20. Ferreira SLC, Caires AO, Borges TdS, Lima AMDS, Silva LOB, dos Santos WNL. Robustness evaluation in analytical methods optimized using experimental designs. Microchem J. 2017;131:163-9. doi: 10.1016/j.microc.2016.12.004.

21. Epshtein NA. System suitability requirements for liquid chromatography methods: controlled parameters and their recommended values. [review]. Pharm Chem J. 2020;54(5): 518-25. doi: 10.1007/s11094-020-02231-w. 